\title{
Developmental and pathogen-induced expression of three barley genes encoding lipid transfer proteins
}

\author{
Antonio Molina and Francisco García-Olmedo* \\ Laboratorio de Bioquímica y Biología Molecular, ETS \\ Ingenieros Agrónomos-UPM, E-28040 Madrid, Spain
}

\section{Summary}

Clones for three barley non-specific lipid transfer proteins (LTP2, LTP3, and LTP4; formerly Cw18, Cw20 and Cw21, respectively) which had been previously shown to inhibit growth of plant pathogens, were selected and characterized from a CDNA library derived from young etiolated leaves. Genes Ltp 2 and Ltp 4 were located in chromosome $3 H$ and gene $L$ tp3 was assigned to chromosome $7 \mathrm{H}$ by Southern blot analysis of wheat-barley disomic addition lines, using gene-specific probes (3'-ends of cDNAs). These assignments were confirmed by the polymerase chain reaction, using specific primers. The three genes were expressed in stem, shoot apex, leaves and roots (at low levels) throughout development. Genes $L t p 3$ and $L$ tp 4 were expressed at high levels, and Lpt2 at low levels, in the spike (rachis, lemma plus palea and grain coats). Neither of the mRNAs was detected In endosperm. The proteins were localized by tissue-printing with polyclonal antibodies in the outer cell layer of the exposed surfaces of the plant, throughout the embryo, and in vascular tissues. Expression levels in leaves were moderately increased by $0.34 \mathrm{M} \mathrm{NaCl}$ and by $0.1 \mathrm{mM}$ abscisic acid and were not affected by cold, drought, salicylate, 2,6-dichloro-isonicotinic acid, ethylene or ethephon. Methyl Jasmonate $(10 \mu \mathrm{M})$ switched off all three genes. Inoculation with Av6 or vir6 isolates of the fungal pathogen Erysiphe graminis Increased the three mRNAs, especially that of LTP4, which reached a maximum nine-fold increase 12-16 $\mathrm{h}$ after infection.

\section{Introduction}

Non-specific lipid transfer proteins (LTPS) in plants are a family of homologous polypeptides of about $9 \mathrm{kDa}$ which have been so designated because of their ability to shuttle different kinds of lipids between liposomes and mitochondria in vitro (Arondel and Kader, 1990; Breu et al., 1989; Watanabe and Yamada, 1986). However, a possible cytoplasmic role in vivo for the LTPs has been questioned because they are synthesized as precursors with typical signal peptides (Bernhard and Somerville, 1989; Sterk et al., 1991; Tchang et al., 1988), a cell wall localization has been found for some of them (Sterk et al., 1991; Thoma et al., 1993), and cell cultures have been shown to secrete them into the medium (Sterk et al.,1991). They have been reported in a variety of plant tissues, including barley aleurone (Mundy and Rogers, 1986; Linnestad et al., 1991), wheat seeds (Simorre et al., 1991), maize endosperm and embryo (Tchang of al., 1988), castor beans (Takishima et al., 1988), spinach leaves (Bouillon et al., 1987), tomato stems (TorresSchumann et al., 1992), tobacco anthers and shoot apex (Fleming et al., 1992), ragi seeds (Campos and Richardson, 1984), and carrot embryos (Sterk et al., 1991). It is becoming evident that multiple LTP genes are present in a given genome and that these are expressed in different specific temporal and spatial patterns (Sossountzov et al., 1991). Involvement of LTPs in cutin deposition has been suggested based on the cell wall location of the carrot EP2 LTP (Sterk et al., 1991), although a cytoplasmic location has been proposed for the maize protein (Sossountzov et al., 1991).

Four LTPs present in crude cell wall preparations from barley leaves are potent growth inhibitors of bacterial and fungal plant pathogens (Molina and Garcia-Olmedo, 1991; Molina et al., 1993). We cloned cDNAs encoding three of these proteins and studied the developmental and pathogen-induced expression of their genes. Deposition of LTPs in the outer cell layer, and in vascular tissues of different parts of the plant, and higher steadystate levels of their mRNAs in response to pathogens were in line with the proposed protective role.

\section{Results}

\section{Cloning of leaf LTP CDNAs}

Nucleotide sequences presented in Figure 1 correspond to cDNA clones encoding LTPs isolated from a library which was derived from 7-day-old etiolated barley leaves. A total of 45 clones were selected out of about $\mathbf{4 0 0 0}$ screened, using two degenerate oligonucleotides deduced from appropriate regions (shaded in Figure 1) of the known amino acid sequences of proteins LTP2 and LTP4 (formerly Cw18 and Cw21, respectively). The sequence encoding protein LTP2 was identified in nine of the 24 clones sequenced, while one of the clones 
encoded protein LTP4 and the amino acid sequence deduced from the longest open-reading frame of one of the remaining clones had an $\mathrm{N}$-terminus identical to proteins Cw20. Cw21 and Cw22 (Molina et al., 1993). This protein, designated LTP3, was closer to protein
LTP4 than to protein LTP2 (78\% indentity versus $67 \%$ ) and differed from both of them by an insertion of three residues (bases $295-303$ in LTP3). Sequence-specific probes were obtained from the divergent 3 'ends of the cDNAs, as indicated in Figure 1, and checked for the
pLTP2

pLTP4

PLTP3

$\rightarrow$ SIGNAL PEPTIDE

PLTP4

PLTP3

ATG GCT CGC ACT GCA GCA ACC AAG CTC GCG CTG GTC GCC CTG GTG GCG GCA ATG CTC CTC GTA GCC GCC GAC GCG 148 Met Ala Arg Thr Ala Ala Thr lys leu Ala Leu Val Ala Leu val Ala Ala Met leu leu vat Ala Ala Asp Ala

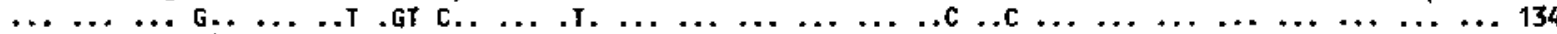
Ala Ser Gin Val G.. $\ldots . . . T \ldots T$ C.....

Ata
AGCAAATCTAGCTATCTCATTGCCACCCTCICCCCGIGAGCCCACCACCACAACTGCACCTTACTCCGTCGAG TAGCCATCTCATCATCTCCAGCTGAGCTCGGTTGCGCTACTATTCCAAACTCATTAGGG 59 GCCGGCTTAGCTCACCACCACTACTAITGCTAGCTIGTGATCGAA 45

CMATURE PROTEIN

GCC ATC ACC TGC GGC CAG GTG AGC TCT GCC TTG GGC CCC TGC GCC GCC TAC GCA AAA GGC AGC GGC ACC AGC CCT 223 Ala 1 le Thr Cys Gly Gln Val Ser Ser Ala Leu Gly Pro Cys Ala Ala Tyr Ala Lys Gly Ser Gly Thr Ser Pro

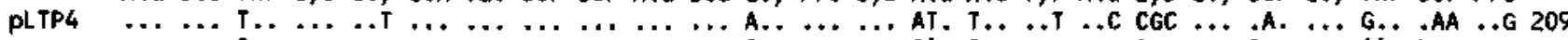

PlTP3

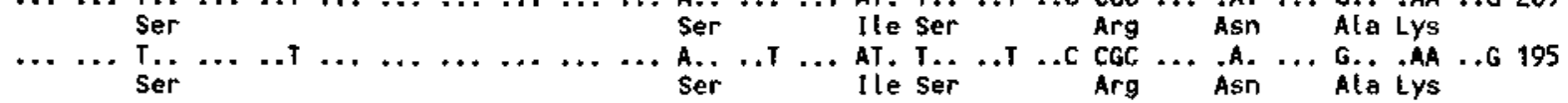

PLTPZ TCT GCG GGC TGC TGT AGC GGA GIC AAG AGA TIG GCC GGC TTA GCG CGG AGC ACC GCC GAC AAG CAA GCT ACG TGO 298 Ser Ala Gly Cys Cys Ser Gly Val Lys Arg Leu Ala Gly Leu Ala arg Ser Thr Ala Asp Lys Gln Ala Thr Cys

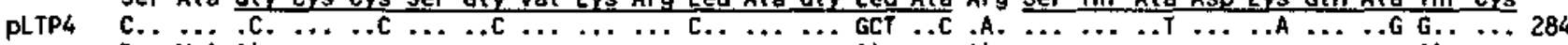
Proval Ala

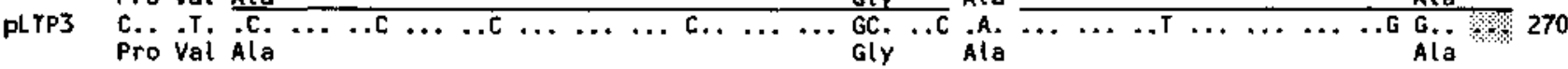

PLTP2

PLTP4

PLTP3

pLTP2

pLTP4

PLTP3

PLTP2

PLTP4

PLTP3

PLTP2

PLTP4

PLTP3

PLTP

PLTP4

PLTP3

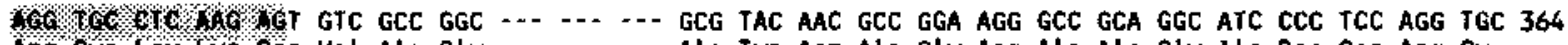
Arg Cys Leu Lys Ser val Ala Gly Ala Tyr Asn Ala Gly Arg Ala Ala Gly lle Pro Ser Arg Cys

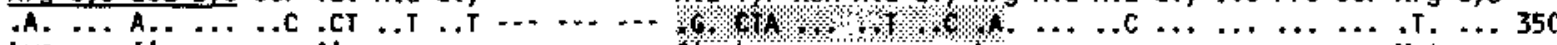

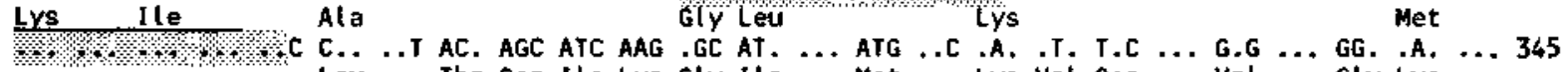
Leu Thr Ser lle Lys Gly Ile Met lys val Ser Val Gly Lys

GGG GTC AGC GTC CCC TAC ACG ATC AGC GCC AGT GTC GAC TGC TCC AAG ATC CAC YGA TCGAACGCCTGCTTCCATCATAG 444 Gly Val Ser val Pro Tyr Thr lle Ser Ala Ser val Asp Cys Ser lys Ile His $\rightarrow$ PROBE

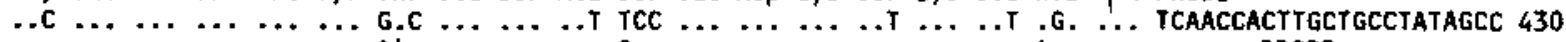
Ala Ser ... $\ldots \ldots \ldots$.... . . . . C.

Phe Pro

ATG TCC AC.

Met Ser Thr

Arg $\rightarrow$ PROBE

-PROBE

CCGCTCATACCTCCAGCGATCGACGCTTGGAAGGTTGAGGTCACATACGCATATATACATATACATGAATAAATCCTCTGTTATGATCTCCATGGGAGA 543 CCAGCAATCGACGCTGAGTACGTTGAGGTCACACATACATACATATATATGAATAAATGCTCTCATATTATCTTCATGTGGGATATATATAGAGAGAGA 520

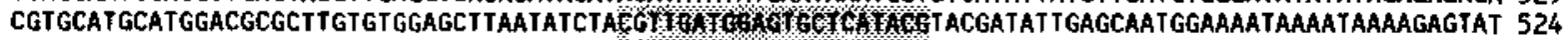

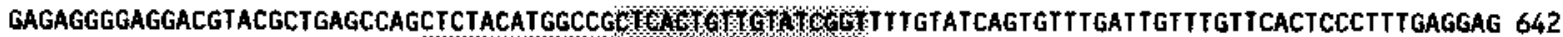

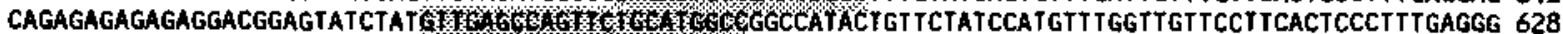
GCCTATGTCTGTACCTTGCACACACACTGTGTGTGTGCGCATATXTATT TACGCGGCATGCATGCACGCGTCCGTATGAGTGACTGAACAGTCATCTLC 623

Figure 1. Nucieotide sequences of CDNAs and deduced amine acid sequences of proleins LTP2. LTP3. and LTP4 fformerly CW18. Cw20 and Cw21, respectively).

Each nucleotide sequence has been numbered independently, excluding gaps introduced for alignment. Identities are indicated by dols and gaps by dashes. Regions of the previously known LTP2 and LTP4 amino acid sequences used to design the degenerate oligonucleotides used to screen the cDNA library are underlined. Regions corresponding to the primers used for PCR amplification are shaded. The 3'-ends of the inserts (used as sequence-specific probes) were cul at the indicated sites with the Pvul (LTP2) and $S_{\text {a }} 3 \mathrm{~A}$ Al (LTP3 and LTP4) restriction nucleases. 
absence of cross-hybridization by the Southern blot technique (not shown).

\section{Genomic organization and mapping of LTP genes}

Southern blot analysis of barley DNA digested with the EcoRI endonuclease, using a mixture of the complete cDNA inserts (LTP2, LTP3 and LTP4) as probe, yielded a pattern with four main bands $(15,9.4,6.8$ and $1.8 \mathrm{~kb}$ in Figure 2a). Sequence-specific probes for LTP2 and LTP3 hybridized with the 15 and $6.8 \mathrm{~kb}$ bands, respectively, and gave practically no signals with wheat DNA (Figure 2a). The LTP2 band was associated with chromosome $3 \mathrm{H}$ of barley, as it was detected only in the wheat-barley disomic addition line for that chromosome, and similarly, the LTP3 fragment was located in chromosome $7 \mathrm{H}$ (Figure 2a). The LTP4-specific probe hybridized with

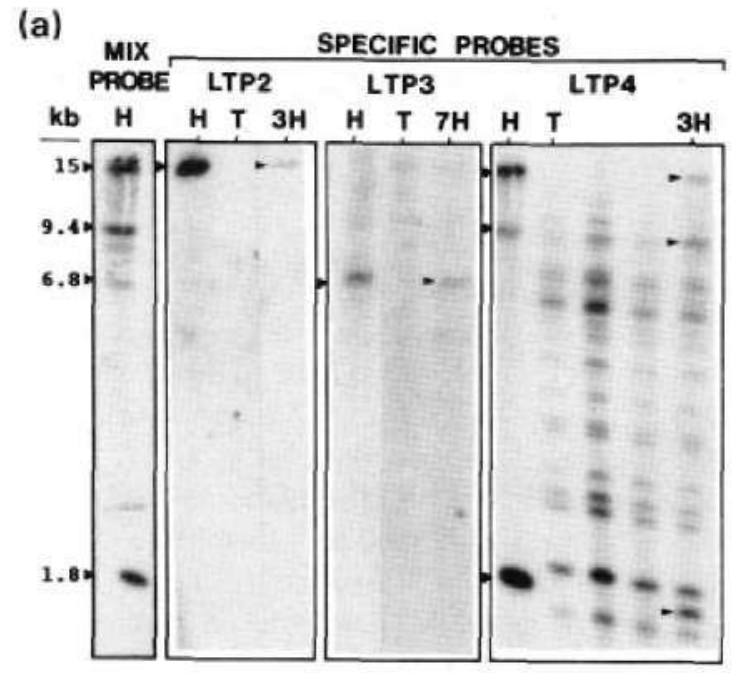

(b)

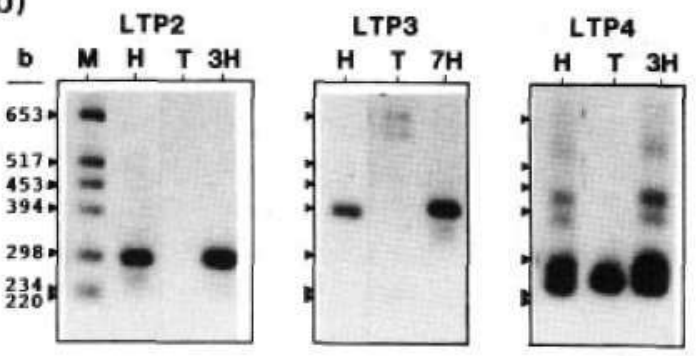

Figure 2. Chromosomal locations of $L$ tp genes.

(a) Southern blot analysis of wheat-barley addition lines. DNAs $(15 \mu \mathrm{g})$ were digested with the EcoRI nuclease. The sequence-specific probes (LTP2, LTP3 and LTP4; see Figure 1) and a mixture of equal amounts of the three complete cDNA inserts (MIX) were hybridized. Markers used to deduce fragment sizes were fragments of $\lambda$ phage digested with nucleases ECoRI and HindIII.

(b) PCR amplification of the indicated DNAs. Size markers (M) used were fragments of plasmid pBR328 digested with nucleases Bg/l and Hinfl. ( $\mathrm{a}$ and b) Only the patterns of Betzes barley $(H)$, Chinese Spring wheat $(T)$, and of the pertinent addition line $(3 \mathrm{H}$ or $7 \mathrm{H})$ are shown in each case. three fragments, including the $15 \mathrm{~kb}$ fragment detected with the LTP2 probe (Figure 2a). The sizes of the fragments $(15,9.4$ and $1.8 \mathrm{~kb})$ hybridized by the short (300 b) LTP4 probe indicated that there was at least a second gene or pseudogene of this type in the barley genome. The same probe detected up to 17 fragments in wheat, which did not overlap with those in barley, except for the $9.4 \mathrm{~kb}$ band (Figure $2 \mathrm{a}$ ). The two non-overlapping bands (15 and $1.8 \mathrm{~kb}$ ) were detected only in the DNA of the $3 \mathrm{H}$ addition line, whereas an enhancement of the overlapping band $(9.4 \mathrm{~kb})$, with respect to the preceding one, was also observed in the same addition line (Figure 2a). To confirm the chromosomal localizations, DNAs from the wheat-barley addition lines were amplified by the polymerase chain reaction (PCR), using the sequence-specific primers indicated in Figure 1. Single bands associated with chromosomes $3 \mathrm{H}$ and $7 \mathrm{H}$ were obtained with the primers for LTP2 and LTP3, respectively (Figure $2 \mathrm{~b}$ ). The LTP2 band was of the same size as that obtained with the cDNA (not shown), while the LTP3 band was about $170 \mathrm{~b}$ longer than expected, which suggested the presence of an intron. The primers for LTP4 gave two closely migrating bands with barley DNA as template; one of them had the predicted size, while the other was slightly smaller and overlapped with the single band obtained with wheat DNA as template. The barley amplification pattern was reproduced when the DNA from the $3 \mathrm{H}$ addition line was used as template (Figure $2 \mathrm{~b}$ ). The amplification results indicated again the presence of at least one more gene or pseudogene of the LTP4 type in barley and allowed confirmation that the LTP4 gene was located in chromosome $3 \mathrm{H}$.

\section{Developmental expression of genes encoding barley LTPS}

Total RNA was extracted from different barley tissues and organs at the times indicated in Figure 3 . The three sequence-specific probes were used to hybridize these RNAs by the Northern blot technique and positive signals were obtained after overnight exposure for all samples shown in Figure 3, except for grain coats with the LTP2 probe, which gave a weak signal even after a week-long exposure. This was also the case for RNAs from roots collected at different stages and hybridized with the three probes (not shown); whereas developing endosperm did not give any signal with these probes even after 7 day exposures (not shown). The main differences among the expression patterns of the three genes were the low steady-state levels of the LTP2 mRNA in different parts of the spike and of the LTP4 mRNA in older leaves. Otherwise, steady-state mRNA levels were similar in all cases, although somewhat higher in stems and, to a lesser extent, in young leaves. 


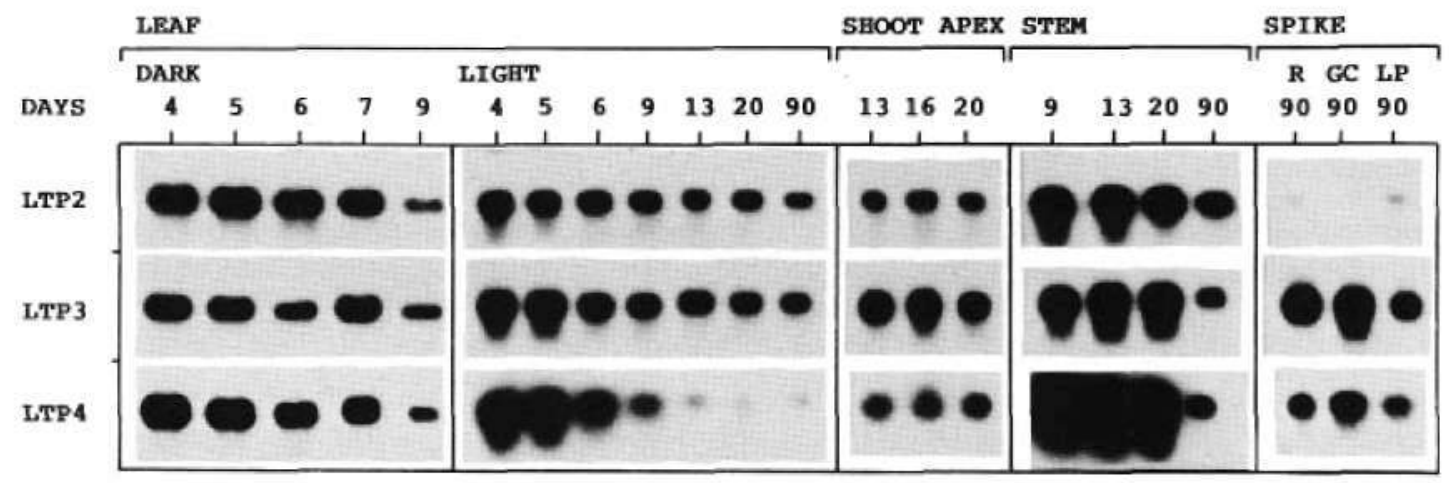

Figure 3. Northern blot analysis of total RNAs (7.5 $\mu$ ger lane) collected at the indicated ages (days) from different plant organs and tissues.

Spikes were separated into rachis (R), lemma plus palea (LP), endosperm plus embryo (not shown) and grain coats (GC). Sequence-specific probes $\left(1 \times 10^{7}\right.$ c.p.m.) were used in each case for the whole set of RNAs and the films exposed overnight. Longer exposures are not shown.

Polyclonal antibodies were raised against a mixture of the previously purified proteins LTP2 and LTP4 and found to recognize all four purified LTPS from barley leaves (not shown). Concentrations of LTPs in different tissues were estimated from the Western blots in the range of $1-4 \times 10^{-5} \mathrm{~mol} \mathrm{~kg}$ fresh weight ${ }^{-1}$.

The distribution of LTPs in different parts of the barley plant was investigated by the tissue-printing technique (Figure $4 a-g$ ). These proteins were mainly accumulated in the outer cell layer of exposed surfaces of the plant, throughout the mature embryo, and in vascular tissues. A substantial fraction of the LTPS could be readily extracted just by dipping an intact leaf (without homogenization or infiltration by vacuum treatment) in extraction buffer, indicating an external location of these proteins in the cell walls of the epidermal layer (Figure 5).

\section{Effects of physical and chemical treatments on steady state levels of LTP MRNAS}

Treatment with abscisic acid increased steady-state levels of all three LTP mRNAs in parallel with that of thionin DG3 (Figure 6a), whereas methyl jasmonate had the opposite effect on the LTP mRNAs under conditions that greatly increased the thionin mRNA (Figure 6b). Exposure to ethylene, ethephon, salicylate or 2,6dichloro-isonicotinic acid had no significant effects on LTP-mRNA levels (not shown).

As it has been reported that some Ltp genes respond to cold and to drought in barley (Dunn et al., 1991) and to salinity in tomato (Torres-Schumann et al., 1992), response of the Ltp genes, under study, to these environmental factors was investigated. Neither of the genes responded to cold treatment, under conditions that caused a 20-fold induction of the sucrose synthase Ss1 gene, a gene which has previously been shown to respond to cold (Maraña et al., 1990), or to drought, under conditions that stimulated four-fold the thionin Th DG3 gene. A small, but significant increase (about twofold) in the steady-state levels of the mRNAs of LTP2 and LTP4 in response to salinity was observed, and no response was seen to wounding in either of the genes.

\section{Response of LTP genes to fungal infection}

Barley line PO3 (cv. Pallas background with gene Mla-6) was inoculated with either isolate $\mathrm{CC} 142(A v 6)$ or isolate CC143 (vir6) of powdery mildew (Erysiphe graminis) by L. Boyd, P.H. Smith and J.K.M. Brown, John Innes Centre, Norwich, UK, and total RNAs were isolated from leaves at different time intervals over $72 \mathrm{~h}$ and subjected to Northern blot analysis, using the three sequencespecific LTP-probes and that for thionin DG3 (Figure 7). All three LTP-mRNA levels were significantly increased, especially that for LTP4, and reached a maximum at 12-16 h after inoculation. No significant differences were observed between the effects of the avirulent and the virulent isolates. The mRNA increases observed for the $L$ tp genes were equal or greater than those of the thionin mRNA used for comparison and all of them took place before differences in growth between the virulent and the avirulent isolates could be detected under the microscope, as reported by Boyd (1993).

\section{Discussion}

The three cDNA sequences reported here clearly correspond to three of the four LTPS previously purified by us from crude cell wall preparations isolated from young etiolated barley leaves and selected because of their strong inhibitory capacity against plant pathogens in vitro (Molina and Garcia-Olmedo, 1991; Molina et al., 1993). The amino acid sequences of these LTPS were similar to other LTPS isolated from ragi seeds or maize 

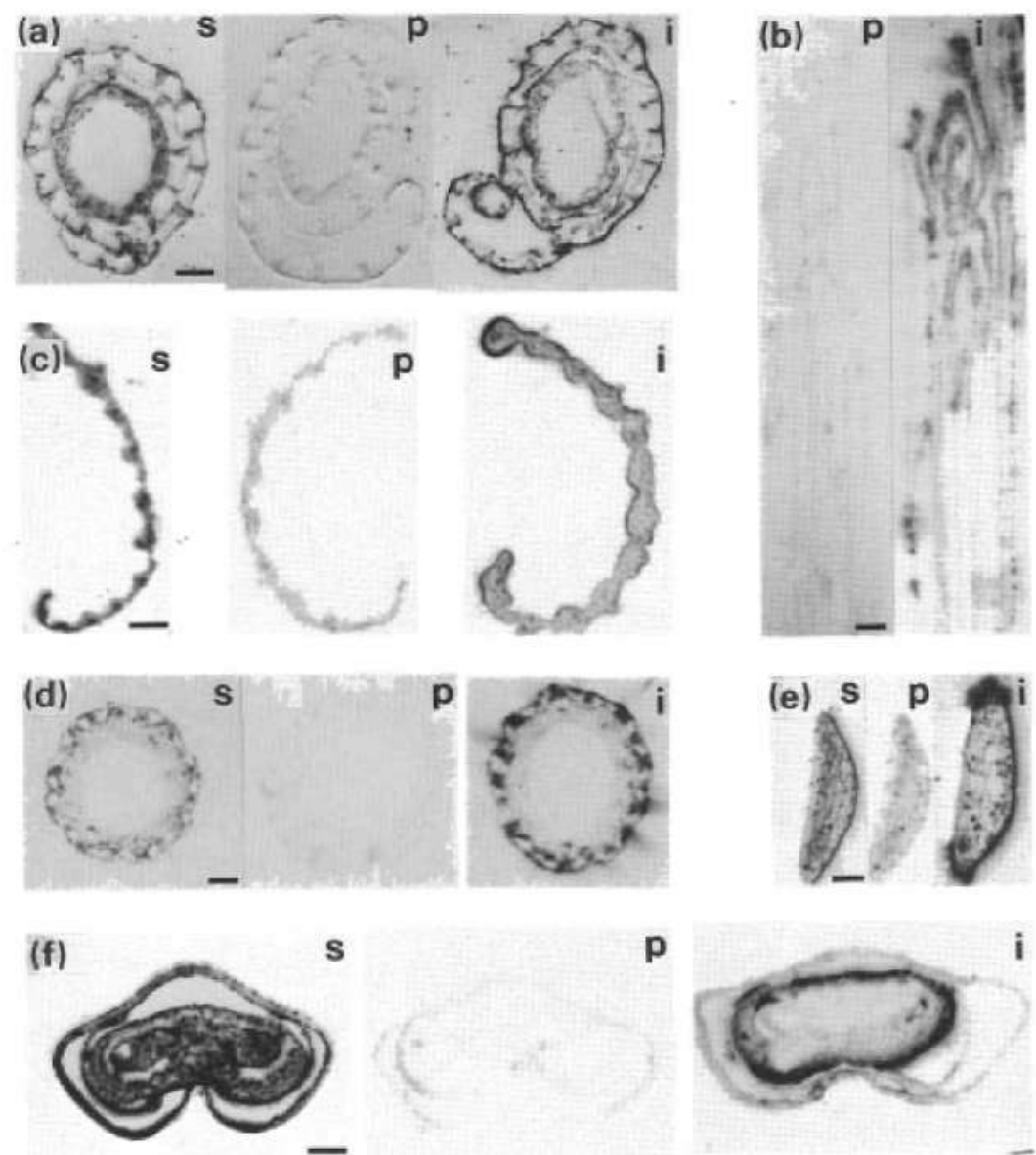

i
Figure 4. Tissue-printing detection of LTP proteins in different sections of the barley plant using an anti-LTP2/LTP4 polyclonal antibody (i); sections stained with amido black (s) and treated with pre-immune serum (p) were used as controls.

(a) Transverse section of leaves plus stem in the upper part of a 90-day-old plant. Epidermal layer and vascular tissues are differentially immuno-stained. Bar represents $0.4 \mathrm{~mm}$.

(b) Longitudinal section of a 12-day-old plant, including the shoot apex. Bar represents $0.5 \mathrm{~mm}$.

(c) Cross-section of leaf from a 12-day-old plant. The epidermal layer is preferentially immuno-stained. Bar represents $0.5 \mathrm{~mm}$.

(d) Cross-section of stem from the same plant and region as in (a). Epidermal layer and vascular tissue are immuno-stained. Bar represents $0.25 \mathrm{~mm}$.

(e) Cross-section of the rachis from the same plant. Bar represents $0.12 \mathrm{~mm}$.

(f) Transversal section of developing kernel, including lemma and palea. Grain coats, lemma and palea are differentially immunostained. Bar represents $0.9 \mathrm{~mm}$.

(g) Longitudinal section of mature kernel hydrated for $12 \mathrm{~h}$. The embryo and the grain coats are immuno-stained. Bar represents $1.5 \mathrm{~mm}$.

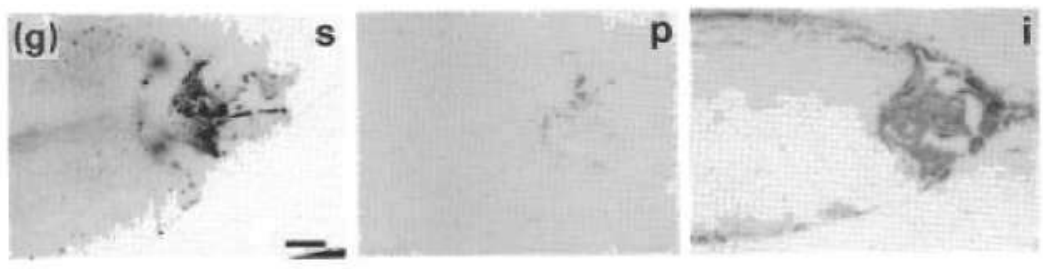

endosperm (61-62\% identical positions; Campos and Richardson, 1984; Tchang et al., 1988) but quite divergent from that described by Mundy and Rogers (1986) in barley aleurone (48\% identical positions) and from that deduced from the cloned cDNA of a barley coldinduced gene ( $40 \%$ identical positions), designated blt4 (Dunn et al., 1991). However, the blt4 cDNA would be almost identical (98\%) to that encoding LTP2 if a number of insertions are introduced (bases numbers 149, 150, 222, 316, 438-449 and 548 in Figure 1). As the BLT4 protein has not been isolated and characterized, it is not possible to discern whether the divergence is real or is the result of sequencing errors.

The Southern hybridization patterns, as well as the PCR results, were consistent with the presence of four closely related $L t p$ genes in the barley haploid genome, three of which would be located in chromosome $3 \mathrm{H}$, probably within a few kilobases of each other, as suggested by a common hybridization band for two of the probes, and another in chromosome $7 \mathrm{H}$. It is interesting to note that the gene for the aleurone LTP is in chromosome 5H (Cannell et al., 1992) and that for BLT4 has been reported in chromosome $3 \mathrm{H}$ (Dunn et al., 1991). The four members of this LTP subfamily (Cw18, 20, 21 and 22; now called LTP2, 3, 4 and 5) that we had previously purified (Molina et al., 1993) would account for the minimum of four genes detected by Southern hybridization and PCR amplification in the present work, but the additional existence of the BLT4 protein and its gene (as separate entities with respect to those described above) cannot be totally excluded.

Both Northern and Western blot analyses indicate that 


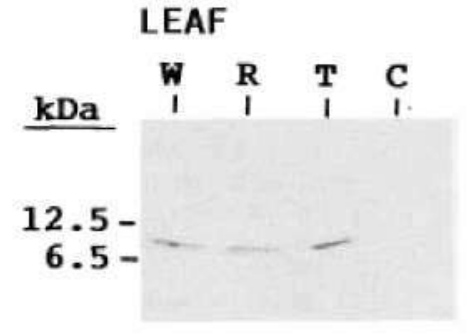

Figure 5. Extraction of LTPs from intact leaves.

Western blot analysis of proteins washed from the leaf surface with extraction buffer $(W)$, extracted from the washed leaf by homogenization with the same buffer $(R)$, extracted similarly from the same weight of unwashed leaf (T), and washed from the intact leaf surface (same weight) with electrophoresis sample buffer, containing $6 \mathrm{M}$ urea (C). Proteins were precipitated from wash and extract solutions with saturated ammonium sulfate and then dissolved in electrophoresis sample buffer, except in (C)

\section{(a) $\mathrm{ABA}$}
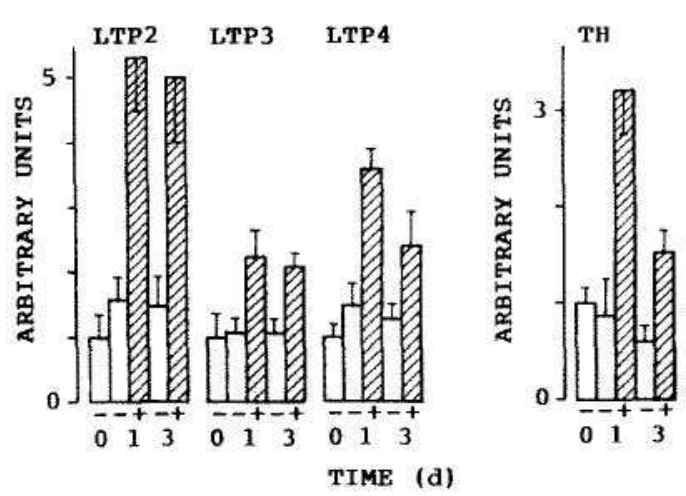

(b) METHYL JASMONATE
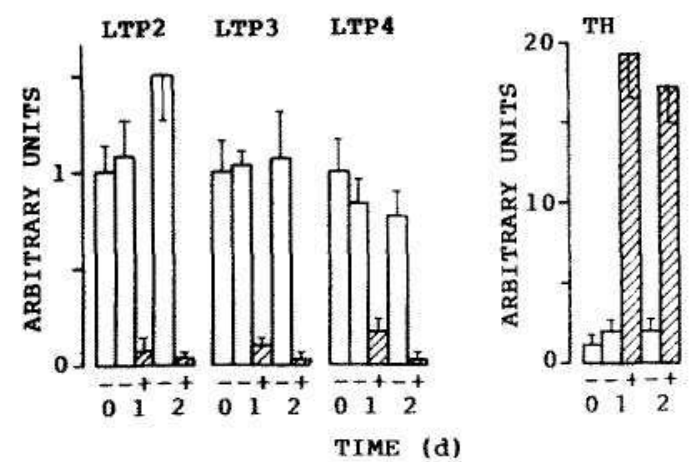

Figure 6. Responses of Ltp and Th genes to abscisic acid (a) and to methyl jasmonate (b).

Three independent filters were processed and analyzed by densitometry Densitometric reading at time 0 was taken as the arbitrary unit in each case. Values represented are the mean of the three experiments and the bars indicate the standard error of the mean.

the Ltp genes studied here are expressed at significant levels in all tissues investigated, except in roots, where they are expressed at very low levels, and in endosperm, where expression is not detected. As judged from immunological staining of tissue prints, in all parts of the
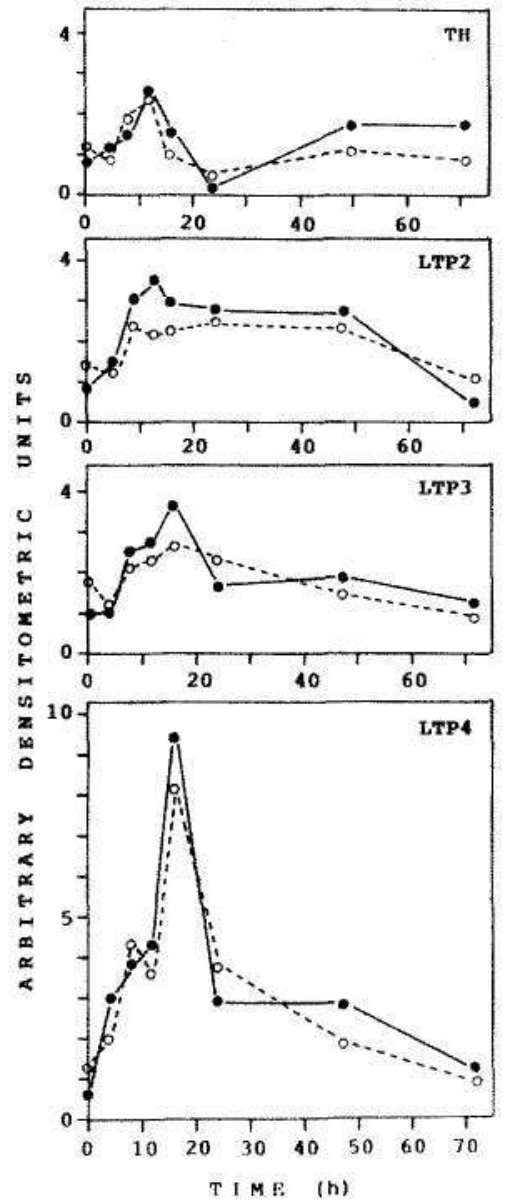

Figure 7. Responses of Ltp and Th genes to infection by virulent ( ) and avirulent $(O)$ isolates of the fungus $E$. graminis.

plant where they are present, the proteins are preferentially located in epidermal cells and in vascular tissues. Their preferential localization in cell walls of peripheral cell layers was corroborated by the fact that a substantial proportion of the proteins could be extracted just by a short dip of the intact organ in extraction buffer. The uneven distribution of LTPS within the different tissues implies that the actual concentrations of these proteins in those cells where they are deposited are indeed very high, well above the average concentrations deduced from the Western blots. The location of LTPS at the exposed surfaces of the plant is well in line with the defense role proposed for them based on their inhibitory properties (Molina et al., 1993). This role would not be incompatible with other developmental role(s).

The negative effect of methyl jasmonate on the expression of $L$ tp genes was simultaneous with the positive one previously described for leaf thionins (Andresen et al., 1992), which has been corroborated in this work, and indicated that the two sets of defense genes can be independently regulated. Jasmonate seems to act as a signaling molecule in stress responses. 
including wounding and pathogen attack (Farmer and Ryan, 1990; Staswick, 1992). The lack of induction of $L$ tp genes by wounding and by elicitors of systemic acquired resistance, such as salycilate or 2,6-dichloroisonicotinic acid, further indicate an independent regulation of these genes with respect to other stress responses. Independent regulation does not imply that the two sets of genes cannot be simultaneously elicited, as observed when the plants were treated with $A B A$.

The response of $L$ tp genes to infection by the fungal pathogen Erysiphe graminis is also in agreement with the proposed defense role of the LTPs. This response was in contrast with the relative insensitivity of these genes to physical stresses. The lack of significant differences between the responses to the virulent and the avirulent isolates might mean that the elicitation is gratuitous in this particular plant/pathogen combination, or that a compatible interaction depends on resistance of the virulent isolate to the defense proteins. As in the case of the ABA treatment, simultaneous expression of both Ltp and thionin genes was observed.

\section{Experimental procedures}

\section{Biological materials}

Cultivated barley, Hordeum vulgare cv. Bomi, was used throughout this study, except for the inoculation with the virulent (CC143; viro) and avirulent (CC142; Av6) isolates of Erysiphe graminis, which was carried out on barley cr. Pallas (line $\mathrm{PO} 3$ with gene Mla6) by Drs L. Boyd, P.H. Smith and K.M. Brown at the John Innes Centre (Norwich, UK). Disomic addition lines of barley $\mathrm{cr}$. Betzes on a Chinese Spring wheat background were the gift of Drs A.K.M.R. Islam and K.W. Shepherd (Glen Osmond, Australia). Probes for the sucrose synthase gene Ssf and the DG3 thionin gene from barley were supplied by $D r P$. Sanchez de la Hoz and by A. Segura (Madrid, Spain).

\section{Cloning of CDNA}

A cDNA library was constructed in vector PT7T3-18U (Pharmacia, Uppsala, Sweden) from poly(A) ${ }^{+}$mRNA (Sambrook et al., 1989) obtained from 7-day-old etiolated barley plants, using the Time Saver cDNA Synthesis Kit according to the manufacturer's instructions (Pharmacia, Uppsala, Sweden). The library was screened at $55^{\circ} \mathrm{C}$, on Hybond $\mathrm{N}$ (Amersham, UK), with two degenerate oligonucleotides corresponding to regions (underlined in Figure 1) of the known amino acid sequences of proteins LTP2 and LTP4 (formerly Cw18 and Cw21; Molina et al., 1993). Plasmid DNA from the selected clones was purified on Magic MiniPreps columns (Promega, Madison, WI) and sequenced according to Hattoni and Sakaki (1986).

\section{ONA and RNA hybridizations}

DNAs were isolated essentially as described (Taylor and Powell, 1982), digested with EcoRl endonuclase, subjected to electrophoresis in 0.8\% agarose, and translerred to Hybond $\mathrm{N}$ membranes (Amersham, UK) following standard procedures.

Hybridizations were carried out at $65^{\circ} \mathrm{C}$ in $0.5 \mathrm{M} \mathrm{NaPO}_{4}, 1 \%$ SDS, $1 \mathrm{mM}$ EDTA, $100 \mu \mathrm{g} \mathrm{ml}^{-1}$ salmon sperm DNA, and washed according to Sambrook et al. (1989). Polymerase chain reactions were carried out $\left(94^{\circ} \mathrm{C}, 1 \mathrm{~min} ; 56^{\circ} \mathrm{C}, 1 \mathrm{~min} ; 72^{\circ} \mathrm{C} 1 \mathrm{~min}\right)$ with genomic DNA (100 ng per reaction) following standard procedures (Sambrook et al., 1989), and the reaction products were subjected to electrophoresis in $1.8 \%$ agarose gel.

RNAs were purified from frozen tissues by phenol/chloroform extraction, followed by precipitation with $3 \mathrm{M}$ lithium chloride (Lagrimini et al., 1987). Electrophoresis was carried out on $5 \%$ formaldehyde/agarose gels, which were blotted to Hybond $\mathbf{N}$ membranes (Amersham, UK). Hybridization and washing were carried out at $65^{\circ} \mathrm{C}$ according to Church and Gilbert (1984). Ethidium bromide $\left(40 \mu \mathrm{g} \mathrm{ml}^{-1}\right)$ was included in the sample loading buffer to allow photography. Equal sample loads were checked by densitometry (Joyce and Loebl microdensitometer, Gateshead, UK) of the negatives of the U.V. photographs. Quantitation of radioactive signals in Northern blot experiments was carried out by densitometry of three independent fitters.

Hybridization probes were prepared either from the full inserts, or from their divergent 3 -ends (indicated in Figure 1), using the Random Primer Labeling Kit (Boehringer Mannheim, Germany) and $\left[{ }^{32} \mathrm{P}\right]$-ATP.

\section{Western blots and tissue printing}

Polyclonal antibodies against a mixture of proteins LTP2 and LTP4 were produced in rabbits (BAbCO, Richmond, CA). Proteins were extracted from different plant tissues and organs $(5 \mathrm{mg}$ fresh weight) with 2 volumes of electrophoresis sample buffer (Laemmli, 1970), subjected to electrophoresis on $12 \%$ SDSpolyacrylamide gels (Laemmli, 1970), and transferred to PVDF membranes (Immobilon, Millipore, Bedford, MA) according to Towbin et al. (1979). Intact leaves (15 mg) were washed with 3 volumes of extraction buffer (1.5 M LiCl, $0.01 \%$ SDS) for $15 \mathrm{~min}$. The washing liquid was saturated with ammonium sulfate and the pellet resuspended in electrophoresis sample buffer. The washed leaf and an intact leaf (15 $\mathrm{mg}$ ) were homogenized in extraction buffer and the extracts were processed as above.

Tissue-printing was carried out as described Hood ot al. (1991), using pre-immune serum and amido black staining on control prints. Both for Western blots and for tissue prints, the first antibody was used at a 1/500 dilution and the anti-rabbit antibody coupled to alkaline phosphatase (Sigma, St Louis, MO) was used at a 1/5000 dilution. Visualization was with Nitroblue tetrazolium (Sigma, St Louis, MO) and 5-bromo-4-chloro-3-indolylphosphate p-toluidine salt (Sigma, St Louis, MO).

\section{External treatments}

Low-temperature treatment was carried out essentially as described (Dunn ef al., 1991): 15-day-old plants grown on vermiculite $\left(22^{\circ} \mathrm{C}\right.$ day $/ 18^{\circ} \mathrm{C}$ night; $16 \mathrm{~h}$ light) were exposed to $4^{\circ} \mathrm{C}$. Shoot apex and leaves were collected 2 and 7 days after. Water deprivation was achieved by leaving 7-day-old plants, grown as before, on the bench until the appearance of clear symptoms of wilting $(12 \mathrm{~h})$. Salinity treatment was carried out by irrigating 3-day-old plants with $0.34 \mathrm{M} \mathrm{NaCl}$ as described by Ramagopal (1987) and collecting leaves $18 \mathrm{~h}$ later. Abscisic acid (cis-trans isomer; Sigma, St Louis, MO) was sprayed (0.1 mM) 
on 7-day-old plants at $6 \mathrm{~h}$ intervals during $24 \mathrm{~h}$ and leaf samples were collected at 1 day and 3 days. Leaves from 7-day-old plants were floated on a $10 \mu \mathrm{M}$ solution of methyl jasmonate (Bedoukian Reseach Inc., Danbury, $\mathrm{CN}$ ) as described by Andresen et al. (1992) and collected at 1 day and 2 days. The experiment with sodium salicylate (1 $\mathrm{mM}$; Sigma, St Louis, MO) was performed as that with abscisic acid. Ethephon treatment $(20 \mathrm{mM}$ in $0.05 \% \mathrm{v} / \mathrm{v}$ Tween 20) was also carried out by spraying 7-day-oid plants and collecting leaves at $8 \mathrm{~h}, 1$ day, 2 days, 3 days and 4 days. Ethylene (100 p.p.m) was applied on 7-day-old plants in a confined atmosphere during $17 \mathrm{~h}$ and $46 \mathrm{~h}$. A solution of 2,6-dichloroisonicotinic acid (4 p.p.m.; Ciba-Geigy, Basel) was formulated with a wettable powder carrier and applied as a soil drench to 7-day-old plants; the wettable powder alone was used for the mock treatment. Leaves were collected at 2 days and 5 days after treatment.

\section{Infection with Erysiphe graminis}

Barley was planted two seeds per pot and grown according to the method of Martineili et al. (1993). Plant material was inoculated in steel settling towers. Mildew spores were blown into the tower and allowed 2-5 min to settle on to the plants placed at the bottom of the tower. Spore inoculation densities were about 50 spores $\mathrm{mm}^{2}$. Leaf samples were taken up to $72 \mathrm{~h}$ after inoculation and immediately frozen in liquid nitrogen.

\section{Acknowledgments}

The collaboration of J. Di Maio and R. Novitzky (CIBA-GEIGY, Research Triangle Park, NC) in the sequencing of CDNA, of L. Boyd, P.H. Smith and J.K.M. Brown (John Innes Centre, Norwich. UK) in the mildew experiment, of I. Diaz in the microscopic analysis and the technical assistance from L. Lamoneda and J. Garcia are gratefully acknowledged. This work was financed by the Comisión Interministerial de Ciencia y Tecnología (Spain), grant B1O90/0084.

\section{References}

Andresen, I., Becker, W., Schlüter, K., Burges, J., Parthier, B. and Apel, K. (1992) The identification of leaf thionin as one of the main jasmonate-induced proteins of barley (Hordeum vulgare). Plant Mol. Biol. 19, 193-204.

Arondel, V. and Kader, J.C. (1990) Lipid transfer in plants. Experientia, 46, 579-585.

Bernhard, W.R. and Somerville, C.R. (1989) Coidentity of putative amylase inhibitors from barley and finger millet with phosphotipid transfer proteins inferred from amino acid sequence homology. Arch. Biochem. Biophys. 269, 695-697.

Bouillon, P., Drischel, C., Vergnolle, C., Duranton, $H$. and Kader, J.C. (1987) The primary structure of spinach-leaf phospholipid-transfer protein. Eur. J. Biochem. 166, 387-391.

Boyd, L. (1993) Gene expression in barley in response to mildew infection. In Engineering Plants Against Pests and Pathogens, Proc. Juan March Workshop, Madrid, Spain (Ponz, F., GarciaOlmedo, F. and Browning, G., eds). Madrid. J. March Foundation, p. 83.

Breu, V., Guerbette, F., Kader, J.C., Kannangara, C., Svensson, B. and Wettstein-Knowles, B. (†989) A $10 \mathrm{kD}$ barley basic protein transfer phosphatidylcholire from liposomes to mitochondrias. Carisberg Res. Commun. 54, 81-84.
Campos, F.A.P. and Richardson, M. (1984) The complete amino acid sequence of $\alpha$-amylase inhibitor $1-2$ from seeds of ragi (Indian finger millet, Eleusine coracana Gaertn.). FEBS Lett. 167, 221-225.

Canneli, M., Karp, A., Isaac, P.G. and Shewry, P. (1992) Chromosomal assignment of genes in barley using telosomic wheat-bariey addition lines. Genome, 35, 17-23.

Church, G.M. and Gilbert, W. (1984) Genomic sequencing. Proc. Natl Acad. Sci. USA, 81, 1991-1995.

Dunn, M.A., Hughes, M.A., Zhang, L., Pearce, R.S., Quigley, A.S. and Jack, P.L. (1991) Nucleotide sequence and molecular analysis of the low temperature induced cereal gene, BLT4. Mol. Gen. Genet. 229, 389-394.

Farmer, E.E. and Ryan, C.A. (1990) interplant communication: Airborne methyl jasmonate induces synthesis of proteinase inhibitors in plant leaves. Proc. Natl Acad. Sci. USA, 87 7713-7716.

Fleming, A.J., Mandel, T., Hofmann, S., Sterk, P., de Vries, S.C. and Kuhlemeier, C. (1992) Expression pattern of a tobacco lipid transfer protein gene within the shoot apex. Plant J. 26, 855-862.

Hattoni, M. and Sakaki, Y. (1986) Dideoxy sequencing method using denatured plasmid templates. Anal. Biochem. 152. 232-238.

Hood, K.R., Bassiri, R.A., Fritz, S.E. and Hood, E.E. (1991) Biochemical and tissue print analyses of hydroxyproline-fich glycoproteins in cell walls of sporophytic maize tissues. Plant Physiol 96, 1214-1219.

LaemmII, U.K. (1970) Cleavage of structural proteins during the assembly of the head bacteriophage T4. Nature, 227, $680-685$.

Lagrimini, L.M., Burkhart, W., Moyer, M. and Rothstein, S. (1987) Molecular cloning of comptementary DNA encoding the lignin-forming peroxidase from tobacco: molecular analysis and tissue-specific expression. Proc. Natl Acad. Sci. USA, 84, $7542-7546$.

Linnestad, C., Lönneborg, A., Kalla, R. and Olsen, O.-A. (1991) Promoter of a lipid transfer protein gene expressed in barley aleurone celis contains similar myb and myc recognition sites as the maize $B z-M C C$ allele. Plant Physiol. 97, 841-843.

Maraña, C., Garcia-OImedo, F. and Carbonero, P. (1990) Differential expression of two types of sucrose synthaseencoding genes in wheat in response to anaerobiosis, cold shock and light. Gene, 88, 167-172.

Martineill, J.A., Brown, J.K.M. and Wolfe, M.S. (1993) Effects of barley genotype on induced resistance to powdery mildew. Plant Pathol. 42, 195-202.

Molina, A. and Garcia-OImedo, F. (1991) Patent application P9101258 (24.05.91) PCT/EP92/01130.

Molina, A., Segura, A. and Garcia-Olmedo, F. (1993) Lipid transfer proteins (nsLTPs) from barley and maize leaves are potent inhibitors of bacteriat and fungal plant pathogens. FEBS Lett. 316, 119-122.

Mundy, J. and Rogers, J.C. (1986) Selective expression of a probable amylase/protease inhibitor in barley aleurone cells: comparison to the barley amylase/subtilisin inhibitor. Planta, $169,51-63$.

Ramagopal, S. (1987) Differential mRNA transcription during salinity stress in barley. Proc. Natl Acad. Sci. USA, 84, 94-98.

Sambrook, J., Fritsch, E.F. and Maniatis, T. (1989) Molecular Cloning: A Laboratory Manual, 2nd Edn. Cold Spring Harbor, NY: Cold Spring Harbor Laboratory Press.

Simorre, J.P., Caille, A., Marion, D., Marion, D. and Ptak, M. 
(1991) Two- and three-dimensional HNMR studies of a wheat phospholipid transfer protein: sequential resonance assignments and secondary structure. Biochemistry, 30, 1160011608.

Sossountzov, L., Ruiz-Avlla, L., Vignols, F. et at. (1991) Spatial and temporal expression of a maize lipid transfer protein gene. Plant Cell, 3, 923-933.

Staswick, P.E. (1992) Jasmonate, genes, and fragrant signals. Plant Physiol. 99, 804-807.

Sterk, P., Booli, H., Schellekens, G.A., Van Kammen, A. and de Vries, S.C. (1991) Cell-specific expression of the carrot EP2 lipid transfer protein gene. Plant Cell, 3, 907-921.

Takishima, K., Watanabe, S., Yamada, M., Suga, T. and Mamiya, G. (1988) Amino acid sequences of two nonspecific lipid-transfer proteins from germinated castor bean. Eur. $J$. Biochem. 177, 241-249.

Taylor, B. and Powell, A. (1982) Isolation of plant DNA and RNA. Focus, $4(3), 4-5$.
Tchang, F., This, P., Stiefel, V. et al. (1988) Phospholipid transfer protein: full-length CDNA and amino acid sequence in maize. J. Biol. Chem. 263, 16 849-16 855.

Thoma, S., Kaneko, Y. and Somerville, C. (1993) A non-specific lipid transfer protein from Arabidopsis is a cell wall protein. Plant J. 3, 427-436.

Torres-Schumann, S., Godoy, J.A. and Pintor-Toro, J.A. (1992) A probable lipid transfer protein gene is induced by $\mathrm{NaCl}$ in stems of tomato plants. Plant Mol. Biol. 18, 749-757.

Towbin, H., Staehelin, T. and Gordon, J. (1979) Electrophoretic transfer of proteins from polyacrylamide gels to nitrocellulose sheets: procedure and some practical applications. Proc. Natl Acad. Sci. USA, 76, 4350-4354.

Watanabe, S. and Yamada, M. (1986) Purification and characterization of a non-specific lipid transfer protein from germinated castor bean endosperms which transfers phospholipids and galactolipids. Biochim. Biophys. Acta, 876, 116-123.

EMBL Data Library accession numbers X68654 (Ltp4), X68655 (Ltp2) and X68656 (Ltp3). 